Ethiopian Journal of Environmental Studies \& Management 8(Suppl. 2): 966 - 975, 2015.

ISSN:1998-0507

doi: http://dx.doi.org/10.4314/ejesm.v8i2.10S

Submitted: August 11, 2015

Accepted: November 18, 2015

\title{
ENVIRONMENTAL CONSCIOUSNESS AND PRACTICES OF LAND USERS ALONG URBAN WATER BODIES IN GHANA: THE CASE OF KUMASI METROPOLIS
}

\author{
*FORKUOR, D. ${ }^{1}$ AND OTIEKU, E. ${ }^{2}$ \\ ${ }^{1}$ Department of Geography and Rural Development, Kwame Nkrumah University of Science \\ and Technology, Kumasi, Ghana \\ ${ }^{2}$ Institute of Statistical, Social and Economic Research, University of Ghana
}

\begin{abstract}
Rivers and streams are important sources of water for many in the developing world. Rural communities solely depend on them, while urban dwellers rely on them periodically due to inadequate municipal water supply from relevant agencies. However, urbanization and its attendant anthropogenic effects are negatively affecting many rivers and streams, especially in urban centers. This study principally examined the environmental consciousness of land users along the rivers and streams in the city of Kumasi and further analyzed the effects of the state of the rivers on the environment, health and growth of the city. The research was purely qualitative and elicited information from land users along the course of the rivers and also city authorities. Instrument for collecting the information was oral interview and participant observation. The thematic technique was employed to analyze the information obtained. Results from the analysis showed that the environmental consciousness of residents along rivers is very low and has resulted in the waters outlived their usefulness. City authorities show little commitment in protecting rivers in the city. Recommendations have been made mainly to city authorities for effective management of water bodies in the city.
\end{abstract}

Key Words: Environmental consciousness, Water bodies, Rivers, Kumasi Metropolis

\section{Introduction}

Water undoubtedly is a vital resource and the most extensively used by humans, plants and animals (Brennan and Withgott, 2004). Because of its importance to life on earth, nature provided water in abundance and its abundance in terms of natural resources is next only to air. It is estimated that water constitutes about $71 \%$ of the earth (Miller, 1998). Moreover, the human body consists mainly of fluid of which water constitutes the largest (Christopherson, 2002). Water is therefore the source of life and humans must take good care of this resource.

*Corresponding author: Forkuor, D.
However, many rivers and streams worldwide have been negatively affected by anthropogenic factors which threaten their very existence. Indeed, pollution remains the greatest threat to the quality and quantity of the world's water resources. Proper management of the world's water resources is necessary if water crisis or water-induced wars are to be avoided in the near future. In the Middle East, the region is expected to face water crisis in terms of quantity and quality in the not distant future (Miller, 1998; Christopherson, 2002). The situation is anticipated because the three

Email: bomsonsempaa@yahoo.com 
major river basins in the Middle East - the Tigris, the Euphrates and the Jordan are adversely being affected by human activities.

In Ghana, rivers and streams flowing in mining communities are constantly and defiantly being polluted by mining activities (Ghana, 2012a). Unapproved structures for residential, religious, industrial, educational and commercial activities have been allowed along the banks and valleys of the rivers in Ghana (Forkuor et. al., 2012). The combined effects of all these undoubtedly pose a great threat to human lives and water bodies including their aquatic lives.

The Kumasi metropolis is no exception to the above situation. Almost all water bodies in the city are drying up and prone to pollution due to infrastructural development (Mensah-Bonsu and OwusuAnsah, 2011).

As a result of the careless Ghanaian attitude towards water resources, several research works have been undertaken by government, academia, professionals and non-governmental organizations on the management, protection, preservation and water quality. However, there is very little knowledge about the environmental consciousness, perception, attitude and practices of residents living or working along these water bodies. This article is set out to examine the level of environmental consciousness and practices of residents along water bodies in the Kumasi metropolis and further assess the efforts the government has made to protect water bodies in the city. Further, the study outlined the effects on the state of the water bodies on the environment and the health of both humans and aquatic lives.

\section{Study Area}

Kumasi is the second ranked city in Ghana and covers an area of 254 square kilometers (fig. 1). The city is located within latitude $6^{\circ} 35^{\prime}-6^{\circ} 40^{\prime} \mathrm{N}$ and longitude $1^{\circ} 30$ ' $^{\circ} 1^{\circ} .35^{\prime} \mathrm{W}$ (Adarkwa, 2011). Its population is estimated to be $2,035,064$ with a growth rate of $5.4 \%$ (Ghana, 2010). The dominant economic activity in the city is commerce.

In terms of drainage, the city falls within the Pra River basin which is among the three principal river basins in the forest zone of Ghana. Principal rivers draining the Kumasi metropolis are Nsuben, Owabi, Sisai, Aboabo, Subin and Wiwi Rivers. Three of these principal rivers (Sisai, Aboabo and Wiwi) were studied for the purpose of this research. The Sisai is the major river among the studied rivers and its basin includes the Subin, Aboabo and Wiwi Rivers (figure 1). The Sisai flows southward to join the Oda River at the outskirts of the metropolis. The Oda River is one of the four principal tributaries of the Pra River. 

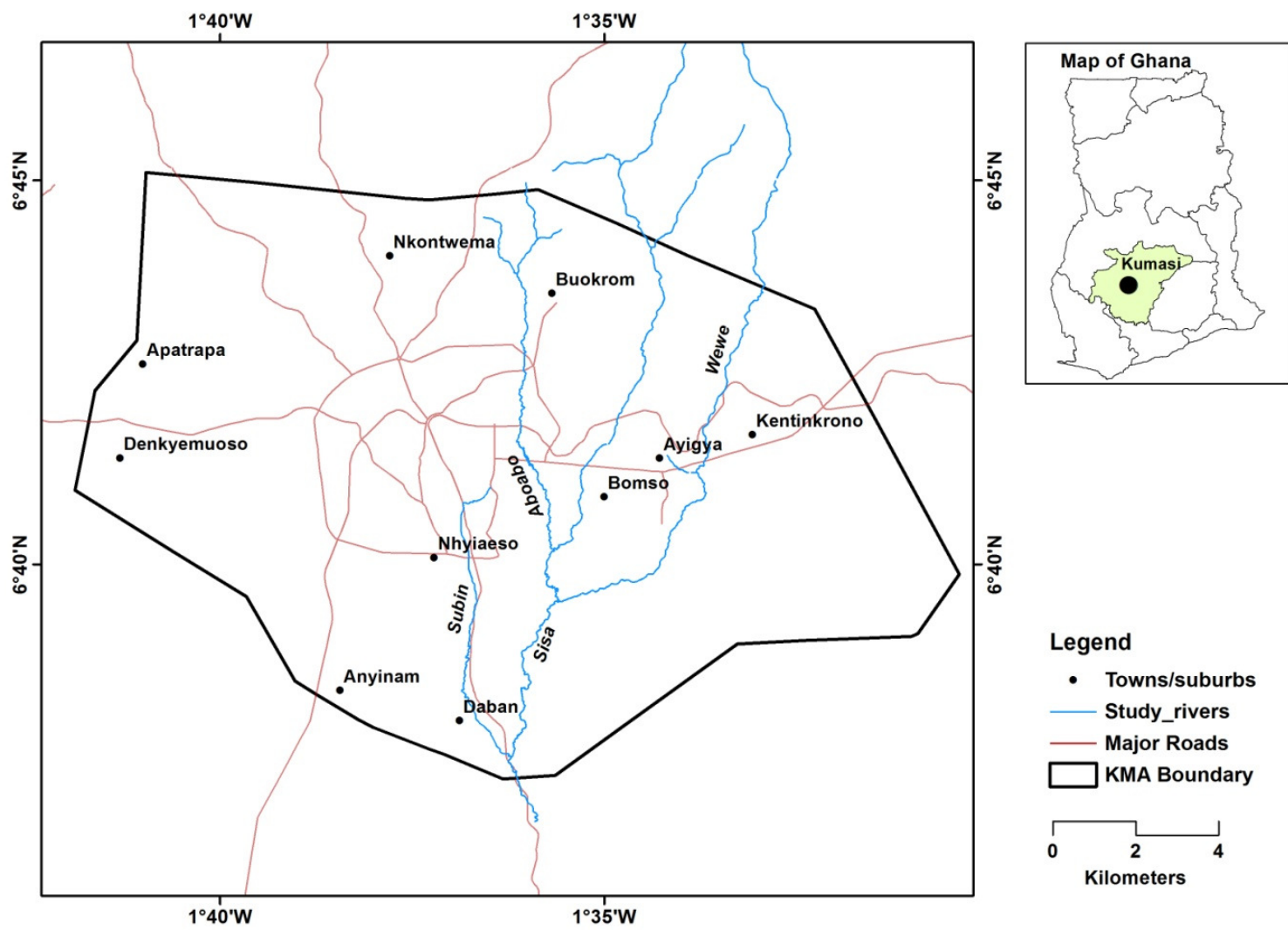

Figure 1: Map of Kumasi showing the studied rivers

\section{Methodology}

The study was qualitative. The qualitative technique was appropriate because it allowed the researchers to study in depth the actual feelings, concerns, practices and environmental awareness of residents living or working along rivers and streams. That is, whether residents consider the resource critical to the survival and healthy lives of the city inhabitants as well as prospect for the development of the city. Primary data on respondents' consciousness for the care of urban waters and their knowledge of the health and environmental implications of their actions were obtained from residents (living or working) along the rivers. To ensure triangulation, further primary data were obtained from the Water Resources Commission and city authorities (KMA). Secondary data were also obtained from the Environmental Protection Agency and the Water Resources Commission. The simple random and purposive sampling techniques were used to select a sample size of 62 (table 1). To obtain a fair representation of the consciousness and practices of residents and commercial workers along the rivers, samples were drawn from various portions of each of the three rivers. Commercial workers included charcoal burners, fish mongers, furniture workers and vegetable farmers. The researchers sampled these commercial workers because their activities were performed close to the rivers. The face-toface unstructured interview technique was used to elicit information from households and commercial workers along the rivers. Even though, this technique was tedious in view of the accumulation of extensive data, it was the best option as it allowed the investigators to elicit rich and useful information from respondents and also enabled the investigators to have a deeper understanding of the attitudes and practices 
of respondents toward the rivers. The structured interview was used to obtain data from the two government institutions. The government institutions were the
Kumasi Metropolitan Assembly (KMA) and the Water Resources Commission. Participant observation was also key in gathering information for the investigation.

Table 1 Sampled population

\begin{tabular}{lllll}
\hline Description & Sisai & Aboabo & Wiwi & Total \\
\hline Households & 9 & 9 & 9 & 27 \\
Commercial workers & 8 & 5 & 8 & 21 \\
Building /Structure owners & 6 & 6 & - & 12 \\
Water Resource Commission & & & & 1 \\
KMA & & & & 1 \\
\hline
\end{tabular}

Data obtained was analyzed using the thematic technique. Audio recording of the interviews were played twice and transcribed. The second play of each recording was to ensure that all information had been transcribed. The transcript of each recording was read three times. The first reading enabled the researchers to familiarize themselves with the data and also the identification of emerging and recurrent themes regarding environmental practices and consciousness that affect the survival of the rivers. In the second reading, questions derived from the aims and objectives of the research as well as those emerging from respondents served as a framework for referencing and examining data. With regard to the last reading, the researchers identified specific quotes and statements by respondents that were relevant for discussion and analysis.

Environmental consciousness was measured based on the state of residents being aware of the environmental consequences or benefits of their actions while environmental practices referred to attitude and actions of respondents towards the rivers.

\section{Result and Discussion}

\section{State of Water Bodies in the City}

Rivers and streams are the major water bodies in the city. The rivers were heavily polluted and pollutants included household raw refuse and sewerage, waste substances from commercial activities (both liquid and solid) and faecal matter. The Wiwi and Sisai Rivers had growth of mangroves along their courses. The Aboabo and Sisai Rivers, by observation, were the most polluted of all the rivers studied. This observation was collaborated by the KMA in an interview with the Public Relation Officer. The abuses are in respect of discharges of raw solid waste (mainly household refuse) and liquid waste from households. Aquatic lives in these two rivers were virtually absent. The colour of the rivers was dark instead of the normal colourless state. The Wiwi River was observed to be the least contaminated because its colour was relatively normal. Deposition of raw solid waste which is characteristic of all the rivers studied was absent. A portion of the river, however, is contaminated near the confluence with the Sisai with refuse from residential homes. It is significant to note that vegetable farms cover extensive portions of the course of the Wiwi River especially at KNUST but, the same cannot be said of the other two rivers. The researchers did not find any form of farming along the courses of the two rivers.

Both the Sisai and Wiwi suffer from extensive growth of mangroves that obstructs the free flow of their waters. Some of the weeds were 10 meters high. 
Authorities at the KNUST as part of their social responsibility occasionally remove the mangroves and dredge the Wiwi River for the stretch that falls within the boundary of the university. According to residents, the Sisai River had been dredged twice with the first one occurring in 2009 and the second in 2013. They were however unable to tell the institution or organization that dredged the river channel. According to residents living along the river, the dredging had brought much relief to them because the perennial flooding they suffer had stopped.

Physical structures (mainly residential, religious and wooden structures) have extensively been developed in the valleys of the rivers under study. The structures are built mainly on the courses of the rivers obstructing their flow and expansion. Car washing bays have also been built on the courses of the Sisai and Wiwi rivers. It should be noted that the Wiwi River had no physical structure developed along its course. The worst affected was the Sisai where apart from residential houses, commercial activities including smoking of fish, palm-kennel processing, cattle ranch, charcoal burning among others go on close to the course of the river. Figure 2 shows the Sisai River with commercial structures (wooden cattle ranch and fish smoking) developed at the right bank of the river.

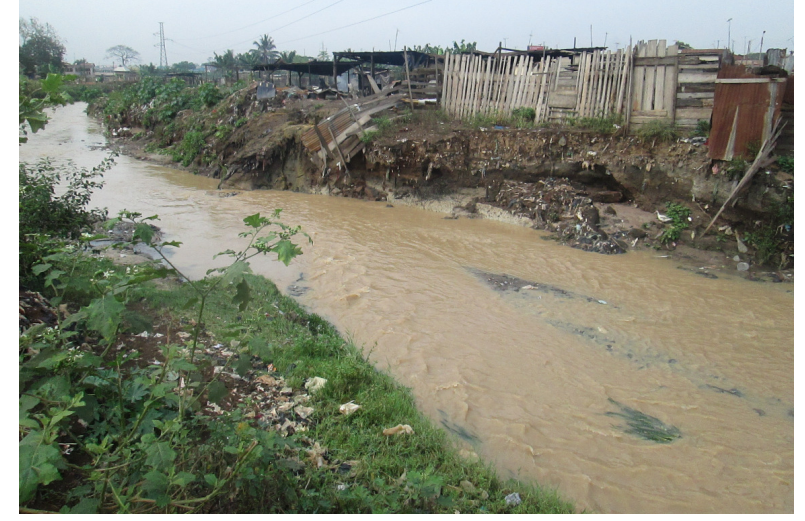

Figure 2: Commercial Structure Development along the Sisai River
Environmental Consciousness and Practices of Residents in the City

The environmental consciousness of people living and/or working close to the rivers was found to be very low. What was found to be adequate was their knowledge of the important role water play in the life of human kind. Many of the respondents catalog the various uses to which water is put. Some of the respondents quoted the phrase: "Water is life," but surprisingly, none was able to explain why water is life. Despite the respondents' knowledge about the central role of water to man's survival on earth, most of the residents and commercial workers saw nothing wrong with the state of the rivers as described above. To them, once they are able to obtain water from other sources (pipeborne water and ground water) for their household activities, there was no need to worry about the state of the rivers. The few that cared were those respondents who had lived in the community prior to the abuse of the rivers.

The common property concept was deeply rooted in the minds of the respondents and therefore found it unnecessary to take personal care of the rivers. Residents considered the rivers as a common property (gift from God) that any member of the community can use at any time and any how without any form of restriction. Urbanization and its anthropogenic factors had therefore wiped out completely the tradition and cultural practice of the Ghanaian to care for water bodies as the abode of the gods and spirits that guide towns or communities.

To some of the respondents, especially along the Sisai River, the continual existence of the river was a nuisance especially during periods when it floods and makes entry and living in their homes uncomfortable. Indeed, those respondents who live in the valley of the Sisai River had wished that the river had dried up. 
This is in view of the efforts the community had made to kill the river. One of such respondents commented:

"This River is very stubborn, when it appears that we have been successful in killing it, oh, only one rain and the river is back to active flow. It is really making our stay here uncomfortable"

Other category of respondents had not even thought about the fact that their activities (discharging sewerages from their homes, dumping of refuse, building and living in the valley of the rivers, etc) are threat to the survival of the rivers which have further consequences on their health and national development. Yet, other respondents were of the opinion that dumping of pollutants into the rivers does not in any way pose a threat to the survival of the rivers. They argue that when it rains, the pollutants are carried away by the rain water and that cleans the river. The careless attitude and practices of these residents toward the rivers stems from the fact that they do not use the raw water for any household activity as compared to villages downstream. Further, the rivers are considered as obstacle to their efforts in making maximum use of the limited land resources. The owner of a house at the banks of the Sisa River recounted how the community decided to dump refuse at the banks of the river so as to claim land from the marshy valley. He stated:

"My father used to wake me up around 3:00 a.m. every day to direct members of the community where they should dump the refuse so as to contain the river and to create land for development."

The philosophy of this respondent is that: "Man must challenge the river not to displace him."

Such respondents were of the opinion that rivers must flow only in their channels and once that is respected, the river had been cared for. It would therefore be wrong to reserve the entire valley of a river as part of the river that is not to be used by man. Obviously, these respondents are not aware of the harm their actions are causing the water ecosystem.

The last category of respondents were however aware of the environmental and health consequences of the state of the rivers. During the field survey, a respondent expressed his concern about the Aboabo River in the following words:

This river would be crying if it is a human being. It is being hit every day with toilet, refuse, unused utensils and all the 'forking jars' of households. Have you (referring to researchers) seen how dirty the water is?

Seeing the genuine concern of this respondent for the river, he was further asked about the efforts he had made as a resident to correct the bad practices of the community. The phrase below was his response:

"Master, they will ask me whether I am the owner of the river. Some will even fight with me. So I don't want any problem."

Another respondent along the Sisai recounted how members of the community used to drink, swim and wash their cloths with the water of the Sisai River in the 1970s and early 1980s, but had to stop from the late 1980s as a result of extensive pollution of the river with refuse and faecal matter. It was established during the field survey that women were the main culprits in this case as they direct household refuse to the rivers. However, the women did so with the approval of the men who are leaders in the communities.

\section{Health, Environment and Development} Implications of the State of the Water Bodies

Human activities and practices going on in the valleys of these rivers include vegetable farming, physical structure development, fish smoking, charcoal burning, palm kennel production and car washing bays. In as much as these activities create income and thereby reduce 
urban poverty, the water ecology is also threatened with these practices as well as the health of residents downstream who use the water for their household activities. The destruction of vegetation along the rivers to allow for vegetable farming and other commercial activities exposes the water to excessive evaporation as well as their water holding capacity. The total effect is the shrinking of the sizes of the rivers and added to the extensive pollution would subsequently result in their extinction. Moreover, the situation can further accelerate the lowering of the water table which would lead to the premature drying up of boreholes and wells. Meanwhile, boreholes and wells are equally important sources of urban water supply in Kumasi and Ghana (Ghana, 2010; 2012b; Braimah and AdomAsamoah, 2011). Already, some respondents indicated that the sizes and volume of water in the river channels have reduced considerably.

It was clear from the information obtained from the field that the water in the rivers are not used by the urban dwellers for household chores basically because of their consciousness of the health implications in its usage. Residents at the lower course of the rivers rather use the water for drinking and other purposes. A respondent at Anloga (one of the communities where the Aboabo flows through) shared his experience when he went to a village to transact business and requested for water from a house. After drinking the water, the host remarked:

'This is the water you pollute in Kumasi and God cleans it for us to drink here.' According to this respondent, he nearly vomited after hearing that comment.

Though nature has set in motion natural processes of treating polluted water, when the extent of pollution is great as it is being done to the Aboabo and the Sisai rivers, nature is unable to treat itself. With the absence of artificial treatment, the health status of those who consume the raw water as a source of drinking water is greatly affected (McDonald and David, 2002; Pandey, 1997). This is as a result of pathogenic bacteria, viruses and parasitic organisms carried by the rivers. Users of such water may contract diseases such as cholera, elephantiasis and bilharzia. Moreover, the turbid nature of the rivers limits the extent of sunshine on the surface and the penetration of light in the water. This caused the destruction of biodiversity in the rivers' ecosystem. Polluted water therefore affects the health status of both human and animals in all communities where the polluted water flows. As Marstrand puts it: "Water therefore serves as the vehicle for the transportation of diseases" (Marstrand, 1991). Also, reclaiming of swampy areas for the construction of physical structures and commercial activities leads to the loss of water as a result of the exposure of water to the sun and it encourages haphazard spatial development (Forkuor, 2012). It was observed that the structures developed in the valleys of the rivers had no spatial pattern and almost all were sub-standard.

Rivers and streams are part of nature and taking good care of them enhances the aesthetic beauty of the city which can open up other developmental opportunities such as increasing the number of tourists into the city.

If nothing is done to the present state of the rivers in the city of Kumasi, inhabitants of the city would not benefit from the enormous advantages associated with water resources, and national development would be retarded. The revelations in this research therefore support the call to perceive development in the light of sustained environment. Once the environment of which water occupies a central part is taken care of, national development on a sustainable basis will be 
assured and both present and future generations shall enjoy life to the fullest.

\section{Management Efforts by City Authorities}

City authorities had shown little commitment in preventing the pollution of the city's waters. This is manifested in the fact that the KMA does not have a policy or a single document purposefully designed for the management of the city's water bodies. They rather depend on the national institutions (Ghana Water Resources Commission and the Environmental Protection Agency) to lead in the management of the city's water resources. Their argument is that the Water Resources Commission (WRC) is a body mandated by the government to manage water resources in the country. The Environmental Protection Agency (EPA) is also mandated to manage the natural environment. But in as much as these institutions have brilliant policies to manage the environment and water resources, they are not adequately resourced to manage the waters at the regional levels. The WRC office in Kumasi that is responsible for managing surface water in the vast Pra basin has only three staff (one as a permanent staff and the remaining two are on one - year renewable contract). In addition, the office complained of small office space and inadequate funds for its day-to-day operations. Since its establishment, the WRC in Kumasi had been depending on Internally Generated Fund (IGF) for its day-to-day administration. These difficulties limit the extent to which the institutions can spearhead the management of the water resources and the natural environment in the city.

In an ad hoc measure to ensure the free flow of the rivers and subsequently prevent flooding, the KMA has charged its nine sub-metropolitan units to facilitate periodic dredging of rivers flowing within their area of jurisdiction. In accordance with national policy on sanitation, the KMA itself organizes monthly clean-up exercises to de-silt the city's rivers and built-up drainage systems (gutters) that flow into the rivers. The respondent from the KMA admitted that these management practices had so far not been very effective. Probed further, the respondent could not give reasons why this ad hoc management strategy had not been working. Public education on the importance of caring for the water bodies in the city was absent in the programmes of the KMA.

In effect, very little is being done by the KMA to stop the discharge of waste substances into the rivers of the city. At Anloga and Sisai Akyi communities, the KMA had located two refuse collection bins just close to the Sisai River. In addition, a public toilet facility had been built close to the river. For whatever good intention the KMA had in locating these utility services close to the river, it does encourage perpetuation of the act of disposing raw household refuse plus fecal matter into the river. This is because inherently, city authorities are encouraging directional flow of refuse towards the river. To make matters worse, residents have to pay before they could access both facilities and those who are unable to pay for the services easily dispose of their waste into the river. Or "rational residents" would opt for the free service rather than paying to dump refuse or ease him/her self. With respect to the development of physical structures in the valleys of the rivers, the KMA through the Town and Country Planning Department conducts routine checks on the city's rivers to ensure that any unauthorized structures inhibiting the free flow of the rivers are demolished in accordance with the new Buffer Zone Regulation Policy by the Water Resources Commission of Ghana. The researchers found this initiative to be ineffective because countless permanent 
and temporal structures that are threats to the rivers were found in the valleys of the rivers. A respondent complained about the refusal of the KMA to facilitate the relocation of an electric pylon that had almost being eroded by the Sisa River. This according to the respondent was evidence that the KMA is less concerned about the people living along the river.

\section{Conclusion and Recommendations}

The research findings have brought to the fore the careless view and practices on water resource by land users along the rivers of the city and subsequently proved that such inhabitants have lost their cultural values on care for water. The conscious actions of respondents are to the detriment of water bodies of the city. Such inhabitants are ignorant about the environment and the need to conserve and preserve it for future generations and to ensure sustainable development. The water bodies in the Kumasi metropolis are not properly cared for by both city authorities and residents. The rivers studied are experiencing excessive pollution from household and commercial sources. Unfortunately, those involved in the unfavourable practices do not belief or know that their actions are threat to the existence of the water bodies, its aquatic life and putting into danger the survival of the present and future generations. Because of the poor consciousness of residents and the long period of practice of the act, solution to the problem should be more of a policy enforcement and public sensitization.

Drawing from the discussion, it is imperative to assert that much needs to be done in the area of specific policy regulation with regard to the management of rivers in Kumasi. The following are recommended as possible solutions to ensure the protection and sustenance of the water bodies and improvement of the environmental consciousness of residents:

1. There should be an enforcement of the Ghana Water Policy by the KMA if true protection of the rivers and streams in the metropolis is to be achieved. In addition, the KMA must develop its own guidelines on human activities in the valleys of rivers and strictly enforce the guidelines. Such policy enforcement would further prevent the development of structures close to rivers in order not to put underground water into jeopardy. True solution to the problem lies in the enforcement of the policies and regulations on water resources.

2. The KMA through its sub-district structures should mobilize volunteers and give them training and sponsor them to go out to educate and sensitize residents and businesses operating close to the rivers about the need to take care of the waters flowing in their vicinity. With time, some of the residents would become convinced and become agents of change in these localities. The subdistrict structures should be resourced to be more responsible for de-silting and clearing of mangroves on the water courses to ensure the swift and free flow of the rivers.

3. Environmental Impact Assessment for projects and activities must be conducted to ensure the proper citing of physical structures along river bodies.

It is hoped that when these are implemented, the waters of the city shall be the cleanest, and the health, environment and development of the city shall be greatly enhanced.

\section{References}

Adarkwa, K.K. (2011). The Role of Kumasi in National Development - 
Kumasi as a Central Place. In K.K. Adarkwa (ed), The Future of the Tree: Towards Growth and Development of Kumasi, Upk, Kumasi. Pp. 14-24.

Braimah, I. and Adom-Asamoah, G. (2011). Provision of Social Services in the Kumasi Metropolis. In K.K. Adarkwa (ed.), Future of the Tree: Towards Growth and Development of Kumasi, Upk, Kumasi.

Brennan, S and Withgott, J. (2004). Environment: The Science Behind the Stories. Pearson.

Christopherson, R.W. (2002). Geosystems: An Introduction to Physical Geography $\left(4^{\text {th }}\right.$ edition), Prentice Hall.

Forkuor, D., Callistus, M., Kyei, P.K. and Forkuor, G. (2012), Changes in Land Use in the Kumasi Metropolis of Ghana - Whose Fault? Journal of Local Government Studies, 4(1): 5877.

Ghana, Republic of (2012). National Integrated Water Resources
Management Plan. Water Resources Commission, Accra.

Ghana, Republic of (2012). Population and Housing Census. Ghana Statistical Service, Accra.

Ghana, Republic of (2010). Development Plan for Kumasi Metropolis (20102013). MLGRD, Accra.

Marstrand, P.K. (1991). Sustainable Development. Commonwealth Secretariat.

McDonald, T.A. and David, K. (2002). Water Resources: Issues and Strategies. Macmillan, London.

Mensah-Bonsu, I.F. and Owusu-Ansah, J. K. (2011). State of the Environment in Kumasi. In K.K. Adarkwa, (ed.), The Future of the Tree: Towards Growth and Development of Kumasi. Upk, Kumasi, pp. 174-194.

Miller, G.T. (1998). Living in the Environment: Principles, Connections and Solutions $\left(10^{\text {th }}\right.$ edition), Wadsworth Publishing.

Pandey, G.N. (1997). Environmental Management. Vikas Publishing, New Delhi. 